\title{
TEACHERS' ERROR CORRECTION STRATEGIES OF STUDENTS' WRITING AT SENIOR HIGH SCHOOL IN PEKANBARU
}

\author{
Tiara Ramadhani ${ }^{1}$ Promadi $^{2}$ Abdul Hadi ${ }^{3}$ \\ ${ }^{123}$ UIN Sultan Syarif Kasim Riau \\ tiararamadhani92@gmail.com
}

Received: 30 Oktober 2019; Accepted 12 Agustus 2021; Published 1 September 2021

Ed 2021; 2 (2): 159-167

\begin{abstract}
ABSTRAK
Tujuan dari penelitian ini adalah untuk mengeksplorasi strategi koreksi kesalahan tulisan siswa yang digunakan oleh guru bahasa Inggris pada siswa kelas satu SMA di Pekanbaru. Ada tiga pertanyaan yang terkandung dalam penelitian ini. Pertama, strategi apa yang digunakan guru bahasa Inggris dalam mengoreksi tulisan siswa. Kedua, bagaimana guru bahasa Inggris menerapkan strategi koreksi kesalahan. Ketiga, faktor-faktor yang mempengaruhi implementasi strategi. Penelitian ini menggunakan penelitian deskriptif kualitatif. Data dikumpulkan dari guru bahasa Inggris dan tiga siswa dari masing-masing sekolah terpilih (SMAN 7 Pekanbaru, SMA Plus Binabangsa Pekanbaru, dan SMA Muhammadiyah 1 Pekanbaru) dengan menggunakan observasi, wawancara, dan analisis dokumen. Teks yang digunakan dalam penelitian ini adalah teks deskriptif. Hasil analisis data menunjukkan bahwa guru bahasa Inggris menggunakan koreksi diri, koreksi teman sebaya, dan koreksi guru dalam mengoreksi tulisan siswa. Dalam koreksi guru, mereka juga menggunakan koreksi satu-satu dan kode koreksi untuk meningkatkan tulisan siswa. Untuk menerapkan strategi koreksi kesalahan, guru bahasa Inggris menggunakan tema yang sudah dikenal, mencoba meningkatkan kosakata siswa, dan menerapkan proses menulis. Kemudian, ada beberapa faktor yang mempengaruhi guru bahasa Inggris menerapkan strategi koreksi kesalahan. Faktor-faktor tersebut sebagian besar karena siswa tidak memiliki kosakata yang cukup dan faktor lainnya adalah guru bahasa Inggris tidak memiliki cukup waktu untuk mengoreksi tulisan siswa. Kesimpulannya, temuan ini menyiratkan guru harus mencoba menggunakan strategi koreksi kesalahan yang efektif, seperti strategi koreksi satu-kesatu untuk mendapatkan hasil yang baik bagi siswa.
\end{abstract}

Kata Kunci: Strategi Koreksi Kesalahan, Koreksi Diri, Koreksi Sejawat, Koreksi Guru, Keterampilan Menulis, Teks Deskriptif.

\section{TEACHERS' ERROR CORRECTION STRATEGIES OF STUDENTS' WRITING AT SENIOR HIGH SCHOOL IN PEKANBARU}

\begin{abstract}
The purpose of this study was to explore error correction strategies of students' writing used by English teachers at first grade students of Senior High School in Pekanbaru. There were three questions contained in this study. Firstly, what are strategies that English teachers used in correcting student's writing. Secondly, how did English teachers implement the error corection strategies. Thirdly, factors influenced the implementation of the strategies. This study used qualitative descriptive research. The data were collected from English teachers and three students of each selected school (SMAN 7 Pekanbaru, SMA Plus Binabangsa Pekanbaru, and SMA Muhammadiyah 1 Pekanbaru) by using observations, interviews, and
\end{abstract}


document analysis. The text used in this study was descriptive text. Result of the data analysis showed that English teachers used self-corection, peer-correction, and teacher-correction in correctiong students' writing. In teacher-correction, they also used one-to-one correction and correction code to improve students' writing. To implement error correction strategies, English teachers used familiar theme, tried to improve students' vocabularies, and applied the process of writing. Then, there were some factors influenced English teacher implement error correction strategies. Those factors mostly because students had insufficient vocabularies and the other factors was English teachers did not have enough time in correcting students' writing. In conclusion, these findings implied the teachers should try to use an effective error correction strategies, like one-to-one correction strategy in order to get good results for the students. Keyword: Error Correction Strategies, Self-correction, Peer-correction, teacher-
correction, Writing skills, Descriptive Text.

\section{INTRODUCTION}

English as a foreign language (EFL) is a universal language. It is compulsory subject to be taught in elementary school, Junior High School, Senior High School and even at all majors in universities in Indonesia. Considering that English has been known as the universal language in the world, the government in Indonesia realizes the importance of English as the key to get information and knowledge in every fields. Indonesia new curriculum 2013 covers four skills in English subject such as listening, speaking, reading and writing. One aspect of the English language that many students consider very difficult to study is writing. Writing in English has been perceived as the most difficult skill among the four skills of English (Hengwichitkul: 2009). Even a native speaker fails to write a good piece of writing (Kukurs: 2012).

Each language has its own rule especially in English. Grammar is the most common rule in writing. But, many students in Indonesia difficult to use the grammar correctly even in vocabulary. This is the problem, which often faced by Indonesian students especially for senior high school level to write in English, and they frequently transfer their native language to English, this phenomena is called Interlanguage. Smith in Fauziati (2009: 127) reveals: "interlanguage studies typically focus on the linguistic and the psychological aspect of second language research. Interlanguage most generally refers to the systematic linguistic behavior of learners of a second or other language, learner of non native language". When students learn a foreign language especially English, they often face a kind of error in their writing, where they apply their mother tongue or first language structure to structure of the foreign language which is different from their native language.

Based on the Senior High School Competency Based Curriculum, the students are expected to be able to communicate in English both in oral and written form. In Indonesia, especially in Senior High School the skill of writing is taught by using genre based approach. Students are introduced to some genres and taught through the model of reading texts where they are explicitly taught about the social function, the generic structures, and the language features of the genres. Senior high school students use English as the foreign language, English subject is compulsory in the curriculum 2013 and one of the subject that students must learn is writing. As the students learn more about English, many errors will appear. Not only they replace one tense with the other tense(s), but also they fail to construct the correct verb forms for these tenses. They often commit the error in their writing production.

Furthermore, in teaching process there are some steps that the English teacher needs to do. They are pre-teaching, whilst-teaching, and post-teaching. Eventhough the teacher 
already good in pre-teaching and whilst-teaching, we can not sure in post-teaching the teacher can get the best result of their students understanding. Final result in teaching process is really important to know if the teacher can deliver the message about the material. Doing the correction especially when teaching about writing in post-teaching is also important for teacher but it still difficult to do because the teacher needs some times to correct all the errors made by students and it still need some processes.

Providing feedback is viewed- both by teachers and students- as an important part of ESL writing instruction (Enginarla: 1994). One type of feedback that ESL writing teachers provide is error correction. It is perhaps the most widely used method for responding to students writing. To know teacher's error correction strategies in writing, the preliminary study was conducted by the researcher at three Senior High School in Pekanbaru; namely SMAN 7 Pekanbaru, SMA Plus Binabangsa Pekanbaru, and SMA Muhammadiyah 1 Pekanbaru. Those were to gain information and to observe how the English teacher corrects their students' writing. Some teachers usually grade students' composition generally and give simply comments without highlighting the errors; while others only single out and correct those mechanical errors such as spelling or grammar errors without pointing out whether the expression and coherence is acceptable or not by native speakers. The correction from teacher may be not effective and the students may not learn from the correction provided by the teacher. By considering the problems as mentioned above has motivated the researcher to conduct this study which is aimed at exploring an effective way to improve students' writing.

\section{METHODOLOGY}

This research employed a qualitative method. A descriptive qualitative research was used in this study. According to Yin (2003) descriptive research is used to describe an intervention or phenomenon and the real-life context in which it occurred. Gay (1987) also states that descriptive research involves collecting data in order to answer questions concerning to the status of the subject.

Informant is a person who gives, or serves as a source of information to another. In qualitative research, the informant is English teacher who know what is going on in the community. In this research, there were two kinds of informants; main informant and supporting informant. The main informants were the English teachers at selected school. There were three English teachers who participated in this research, while the supporting informants are three students of each class who active in learning.

This qualitative research employed the multiple methods of data collection called as triangulation. The techniques used in this research included observation, interviews and document analysis. In this study, two types of interviews were conducted, namely semistructured interviews and focus group discussions (Cresswell,1998). All data were collected in Indonesian, rather than in English, in order to avoid inaccuracies and misunderstanding in the process of data collection, and later in the data anaysis.

In the initial stage of the data analysis, data gathered from interviews and focus group discussions were transcribe in the language they were collected - Indonesian. In the second stage, the transcriptions were categorized according to their classifications related to the research questions, aiming to elaborate the findings by matching the data obtained from the participants with the result from other instruments. The third stage is interpreting the data that was aimed to describe the interview contents. At this point, the collected data were analyzed qualitatively in order to get the correct data. 


\section{FINDINGS}

\section{Teacher's strategies in Correcting Students' Error in Writing}

\section{a) Self and Peer-Correction Strategy}

Based on the data of interviews, the teachers' strategy to help and correct students' writing were by giving the students a chance the let them write their own writing. After that, the teacher guided them to do the discussion.

“...Saya pantau. Saya berikan dulu mereka kesempatan untuk membuat. Nanti mereka membentuk diskusi, partner. Setelah itu baru saya koreksi jalan-jalanlah gitu keliling." (T\#1)

I observed. I gave them a chance to do it by themselves. After that, they discussed, in pair. Then, I checked their writing by walking around the class. (T\#1)

“...Kalau saya biasanya biarkan mereka bekerja sendiri dulu, dan mereka diwajibkan untuk membawa kamus sehingga mereka boleh open dictionary. Kalau misalnya tidak ada dikamus, mereka boleh bertanya kepada saya." (T\#2)

I let them do it by themselves and they must brought dictionary so they can open their dictionary. If they could not find it, they were free asking me. (T\#2)

Based on the interview above, it can be seen in the beginning of writing process the teacher applied self-correction because teachers let their students' to write by themselves. According to Bitchener, Young, and Cameron (2005), self-correction is an indirect feedback where the teacher provides students with choices that would allow them to discern the correct form by themselves. Self-correction deals with students' awareness to correct their own errors. After that, the teachers guided students to do peer correction in the classroom because they asked their students to make a partner or group.

The other data showed some students in this research held negative views of the peer correction and they prefer to do self-correction.

"...Iya, saya juga lebih suka dikerjakan sendiri dulu, biar fokus." (s\#3)

Yes, I prefer to do by myself, so I can focus.

“....Fokus, karena terkadang kalau kita tanya sama teman terus kita sama-sama belajar jadi gak ada yang pro. Lebih baik kita pede aja, nanti kalau misalnya salah terus dikoreksi dan ditanya gitu." (s\#6)

Focus. Sometimes when asking our friends, we did not know which one is true. So, it was better if we confident by ourselves. When there was an error, we could ask teacher. (s\#6)

The students had the same worry as Hughes J. (2005) says "there is a danger that a student may be getting incorrect information from a peer, but careful monitoring on your part can resolve this." Actually, as a teacher we should encourage our students to correct each other in pairs or in group work. It encourages team spirit and has the benefit of reinforcing the language in the other students' own minds as well.

\section{b) Teacher-Correction Strategy}

1) One-to-one Correction

The data gained from observations and interviews showed that teacher also implement one-to-one correction to students. According to James (1998:247) "this conferencing allows both students and teachers a chance to trace the causes of the problems arising from students' writing and feedback, and to develop strategies for improvement."

"....saya koreksi jalan-jalanlah gitu keliling..." (t\#2)

I checked their writing by walking around the class. (t\#2) 
“...Saya jalan-jalan. Koreksinya gitu aja. Jalan satu-satu. Koreksinya sampai semuanya. Nanti sambil mereka mengerjakan saya koreksi. Sambil menulis saya koreksi..” (t\#1)

I walked around the class to check and correct one by one their writing until they finished. When they were writing, I also correcting their writing. (t\#1)

To support teachers' statements, students also said that their teachers usually help them while writing the text in the class.

“...Biasanya mam suka jalan-jalan keliling kelas. Periksa jawaban kami, kadang menolong juga kalau ada kesulitan.” (s\#2)

The teacher usually walk around the class. Checked our writing, sometimes she help us. (s\#2)

“...Iya, mam suka menolong kalau misalnya ada yang tidak ngerti." (s\#1)

Yes, she helped us if we did not understand. (s\#1)

2) Correction code

In order to support students to carry out the revision stage, correction code is used by the teacher.

“...Kalau yang saya koreksi itu biasanya langsung dilingkari. Misalnya ada salah dalam penggunaan kata, kita lingkari pakai pena merah nanti mereka kita beritahu disini letak salahnya. Yang lainnya bisa juga kita minta bantu dengan siswa secara bergantian mengoreksinya bisa juga." (T\#3)

I usually correct their writing by giving the circle. For example they wrote the wrong grammar, then I gave a circle using red pen and I taught them about their error. For other students, we can asked their friends to correct together. (T\#3)

From the interview above we know that the teacher usually gave the correction code by circling or underlining the error using red pen, but the teacher is not only give the circle or underline, they also give the right answer to make students more understand. So, error correction used by teacher was put some notes to remind students about their error. See the picture 5.1 below:

Picture 5.1

Students' Assignment 1

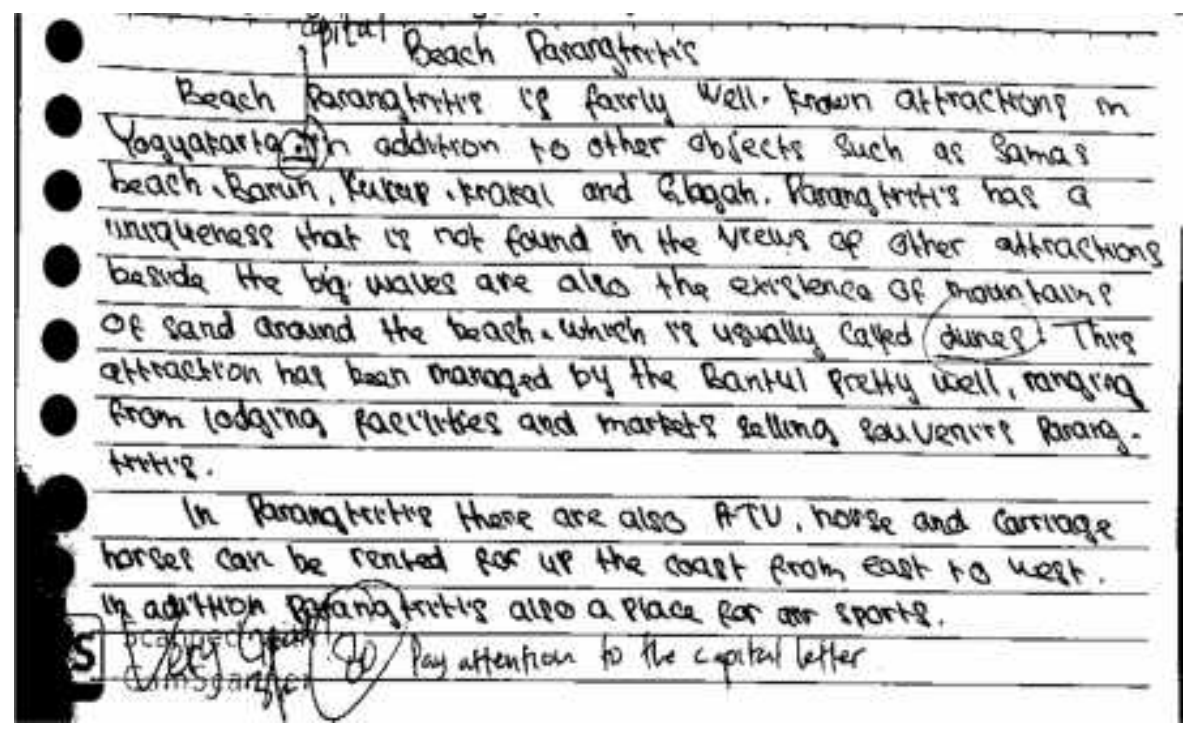

The Picture 5.1 showed that students' had some problem in mechanics, it was the use of capital letter. Some notes to remind students about their error. In another interviews, the teacher also stated the same opinion about correcting students' writing: 
“...Iya, biasanya kalau ada salah penulisan saya koreksi atau digaris bawahi, kemudian bagian atas kalimatnya saya tulis yang benarnya." (T\#2)

Yes, usually if there was an error in writing, I underlined the words and wrote the correct answer. (T\#2)

Rather than a correction code, the teacher prefer to correct the grammar or words in the students' assignment book.

\section{The Implementation of Error Correction in Writing}

a) Used Familiar Theme

Based on interviews with students, they said teachers gave them the familiar theme in order to make them easier in writing the text such as about place, things, or animal:

"....Kemarin sih mengenai tempat." (s\#1)

I wrote about place. ( $\$ 1)$

“....Ada juga tentang hewan. Saya kemarin menulis tentang kucing.” (s\#2)

There was also about animal. I wrote about cat. (s\#2)

“....Kalau saya tentang kipas." (s\#3)

I wrote about fan. (s\#3)

b) Improved Students' Vocabularies

From the interviews, before implementing error correction strategies, such as selfcorrection, peer-correction, or teacher correction, most of the teachers said that their students had low vocabulary so it made them felt difficult in writing English text.

“...Biasanya yang pertama itu saya beri mereka vocab dasar.” (T\#2)

The first thing I do is give them the basic vocabulary. (T\#2)

c) Applied the Process of Writing

“...biasanya ketika saya beri tugas, misalnya teks deskriptif, saya jelaskan dulu awalnya. Saya suruh mereka mengkhayal tentang benda tersebut, kemudian mereka saya suruh apa yang bisa kalian bayangkan dari benda ini. Baru setelah itu saya suruh mereka buat teksnya. Nanti mereka kembangkan sendiri." (T\#2)

When I gave them a task, for example descriptive text, I will explain the definition. I asked them to imagine about that things, after that I asked what they can imagined from that things. Then, they begin to write the text and develop the ideas. (T\#2)

From the interviews, the teacher has to be able to draw the two features to their attentions. It is difficult for some students to write in English. The teacher must motivate them by creating the nice learning atmosphere, persuading them of usefulness of the activity.

In the process of writing, teachers become the main supporters for the students when they are writing in classroom, especially when the students face difficulties.

"...Biasanya mam suka jalan-jalan keliling kelas. Periksa jawaban kami, kadang menolong juga kalau ada kesulitan." (s\#2)

The teacher usually walk around the class. Checked our writing, sometimes she help us. (s\#2)

“...Iya, mam suka menolong kalau misalnya ada yang tidak ngerti." (s\#1)

Yes, she helped us if we did not understand. (s\#1)

From the interviews above we can conclude that teacher is always wellprepared to help students solve their difficulties.

In addition, finding from this current study also shows that the teacher also gave some compliment on students' book. Students also like praise and this type of comment from teacher is usually associated with positive feelings. Alamis (2010) also found that students believed that feedback in the form of praise provided most help for them to improve in their writing. 


\section{Factors Influenced the Implementation of Error Correction Strategies}

a) Lack of Vocabulary

The collected data from teacher's interview showed that the one of the factors made the teacher used error correction strategies because they lack of vocabulary. Most of the student felt difficult when teacher asked them to write a text.

“...Oh agak kesulitan karena mereka agak kurang dalam vocab ya." (T\#1)

They were quite difficult because they lack of vocabulary. (T\#1)

b) Poor Choice of Words

In addition, many of students had poor choice of words. It might be because the students did not know many vocabularies in English, lack of practices and faced difficulties in learning English.

c) Students' Interest

The students ability in writing is vary. In a classroom, there were many different ability and knowledge of students in English. We could not assummed that the students is not good in English because in English there are four skills and the students might only able to master one of those four skills.

d) English teacher did not have enough time

The teachers think that correcting students' writing is a heavy task because they need to read the students' writing and then they have to correct all the writings.

\section{CONCLUSION}

Responding to the research question of this research, the findings showed the following. First, teacher' strategies in correcting students' writing were self-correction, peercorrection, and for teacher-correction were one-to-one correction and correction code. Second, based on findings, teacher correction usually appeared when the students wrote the text in the class. In relation, teacher used correction code to correct the error in writing and gave circle or underlined in students' book. It used to help teacher minimize the time consumed in correcting students' writing. In addition, teachers also give direct feedback on students' book about their error in writing, like giving the compliment to encourage them in writing. The compliment is very useful to make students think that their teacher appreciate their writing. Furthermore, the ways English teachers implement this method is already good because they thought that vocabulary need most attention to improve students' ability in error correction so English teachers implement various way in order to improve students' vocabularies in writing. Teachers' strategy in teaching is also influenced students' writing. Before asking students to write a good text, English teacher should find the effective strategies to improve their students' writing. They cannot expect their students to have a good writing if their teaching strategy is not effective.

\section{REFERENCES}

Bitchener, J., Young, S., \& Cameron, D. (2005). The Effect of Different Types of Corrective Feedback on ESL Student Writing. Journal of Second Language Writing, 14 (3), 191205. https://doi.org/10.1016/j.jslw.2005.08.001.

Brown, H. D. (2004). Language Assessment: Principles and Classroom Practices. NEW York: Cambridge University Express.

Buckingham, L., \& Aktug-Ekinci, D. (2017). Interpreting Coded Feedback on Writing: Turkish EFL Students' Approaches to Revision. Journal of English for Academic Purposes, 26, 1-16. https://doi.org/10.1016/j.jeap.2017.01.001. 
Creswell, J.W. (1998). Qualitative Inquiry and Research Design: Choosing Among Five Traditions: International Student Edition. California: Sage Publications.

Dayyani, Mahdy, \& Shokouh Rashvand Semiyari. (2019). The Impact of Teachers vs Peers Corrections and the Explicit Instruction of DMs on Iranian EFL Learners' Writing Scores. Journal of new advance in English Language Teaching and Applied Linguistics. Vol.1 (2)

Ferris, D. R. (2003). Response to Student Writing: Implications for Second Language students. Mahwah, NJ: Lawrence Erlbaum Associates.

Harmer, Jeremy. (2004). How to Teach Writing. Essex: Pearson Education Ltd.

Hengwichitkul, L. (2009). An Analysis of Errors in English Abstracts translated by Thai University Graduate Students. (Unpublished master's thesis). Srinakharinwirot University, Bangkok, Thailand.

Hughes, J. (2005). Find the right way to right the wrongs Guardian Weekly from www.guardianweekly.co.uk

Husna, Lailatul, et.al. (2013). An Analysis of students' writing skill in descriptive text at grade X1 IPA 1 of MAN 2 Padang. Journal English Language Teaching (ELT), Vol.1 (2).

Hornby. A.S. (2002). Oxford advanced Leaner's Dictionary of Current English Oxford University Press: England.

Hyland, K., \& F. Hyland. (2006). Feedback on Second Language Students' Writing. Language Teaching, 39, 83-101.

Kazuya, S. (2012). Effects of form-focused instruction and corrective feedback on L2 pronunciation development by Japenese learners of English. Language Learning, 62(2), 595-633.

Kukurs, R. (2012). 3 Killers tips on How to Write in English like a Native Speaker. http://www.englishharmony.com/write-like-a-nativee-speaker/.

Long, M. H. (1991). Focus on Form: A Design Feature in Language Teaching Methodology. In K. D. Bor \& R. B. Ginsberg \& C. Kramsch (Eds.) Foreign language research in cross-cultural perspective. Amsterdam: Benjamins.

Pishghadam, R., \& Kermanshahi, P. N. (2011). Peer Correction among Iranian English Language Learners. European Journal of Educational Studies, 3(2), 217-227.

Saito, H. (1994). Teachers' practices and students' preferences for feedback on second language writing: A case study of adult ESL learners. TESL Canada journal, 11(2), 46-70.

Spratt, M. \& B. Leung. (2000). Peer teaching and peer learning revisited: ELT Journal, 54, 218-226.

Sultana, A. (2009). Peer Correction in ESL Classroom. Brac University Journal, 6(1), 11-19. 
Tierney, R. J., \& Pearson, P. D. (1983). Toward a composing model of reading [Reading Education Report No. 43] Champaign, us: University of Illinois at Urbana Champaign. Retrieved from: https://www.ideals.illinois.edu/bitstream/handle/2142/17470/ctrstreadeducrepv01983i 00043 opt.pdf? sequence $=1$.

Truscott, J. (1996). The Case against Grammar Correction in L2 Writing Classes. Language Learning, 46, 327-369.

Wang, Ping. (2010). Dealing with English Majors' Written Errors in Chinese Universities. Journal of Language Teaching and Research, Vol.1, No.3, pp. 194 - 205. doi:10.4304/jltr.1.3.194-205.

Weigle, Sara. C. 2002. Assessing Writing. Edinburg: Cambridge University Press.

Yin, R. K. (2003). Case Study Research: Design and Method. California: Sage Publication Inc.

Zacharias, N. T. (2007). Teacher and student attitudes toward teacher feedback. RELC journal, 38(1), 38-52.

Zan, Li. (2016). Written Teacher Feddback: Student Perceptions, Teacher Perceptions, and Actual Teacher Performance. English Language Teaching, Vol.9, No.8. http://dx.doi.org/10.5539/elt.v9n8p73 